DOI: http://doi.org/10.21698/simi.2018.ab42

\title{
KEY INDICATORS FOR ASSESSING VIABILITY AND RENTABILITY OF RENEWABLE ENERGY PROJECTS
}

Oana-Catalina Tapurica, Ioana-Iulica Mihai

National Research and Development Institute for Industrial Ecology ECOIND, 71-73 Drumul Podul Dambovitei, district 6, 060652, Bucharest, oana.tapurica@incdecoind.ro, Romania

Keywords: renewable energy, environmental projects, indicators, rentability, assessment flow

\section{Introduction}

Developing renewable energy investment projects occurs as a necessity, as there is an increase in building-up renewable energy technologies due to concerns regarding both the climate change and the exploitation of conventional resources. Given the natural conditions for developing either solar or wind energy capacities in Romania, the replacement of the energy systems based primarily on non-renewable sources with new ones, based on alternative energy sources, may seem an adequate strategic option for most energy production companies. So far, the efficiency of a project was assessed by using general indicators methodologies, such as EBRD methodology, which analyses the internal rate of return and the net present value, as core indicators for projects' efficiency. However, using a general methodology for assessing investments in renewable energy, may prove to be a very dangerous process, as achieving performance in an emergent industry requires a multi-perspective analysis which encompasses economic issues (profitability, turnover, expected financial incomes, etc.), as well as social issues (life quality improvement, social benefits, community welfare, etc.) and environmental issues (pollution reduction, air quality improvement, sustainable development, etc.).

\section{Methods}

The assessment of the investment projects aiming the development of renewable energy production capacities should be performed with a two stage method, outlined in Figure 1, as follows:

- in the first stage, the investment is being analysed through a set of global indicators;

- in the second stage, the process involves calculating a set of specific indicators.

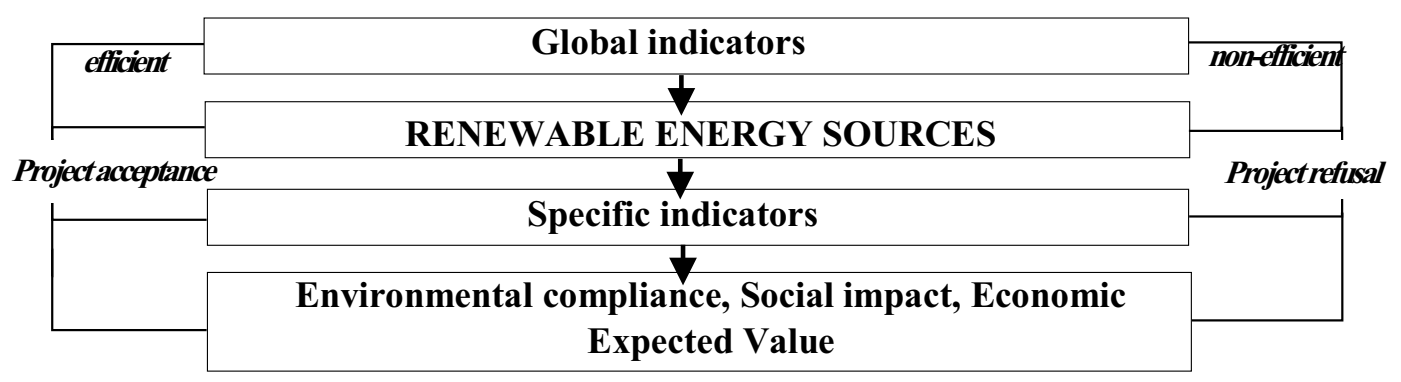

Figure 1. Successive model for assessing the efficiency of renewable energy investment projects 


\section{INTERNATIONAL SYMPOSIUM "THE ENVIRONMENT AND THE INDUSTRY", SIMI 2018, BOOK OF ABSTRACTS}

\section{Results}

Set of global indicators:

- Immobile Capital Specific Efficiency - the investment project is regarded as efficient if the indicator is higher than 1.

$$
\boldsymbol{E}_{\boldsymbol{k}}=\frac{\sum_{h=1}^{d+D}\left(V_{h e n}+V_{h r e c}\right) * \frac{1}{(1+a)^{h}}}{\sum_{h=1}^{d} I_{h}^{*} \frac{1}{(1+a)^{h}}} \text { (monetary income/invested income) }
$$

where: $E_{k} \quad$ - monetary income/invested income - the immobile capital specific efficiency for $\mathrm{k}$ type of renewable energy; $\mathrm{V}_{\text {hen }}$ - monetary units - the annual income during the investment operating period, coming from produced renewable energy transactions; $V_{\text {hrec }}$ - monetary units - the annual income during the investment operating period, coming from green certificates transactions; $I_{h}$ - monetary units - annual investment capital; $1 /(1+a)^{\mathrm{h}}$ the discount rate.

- Opportunity Cost of Capital - the investment project is regarded as efficient if the indicator is higher than 1.

$$
\boldsymbol{C o} \boldsymbol{o}_{\boldsymbol{k}}=\frac{\sum_{h=1}^{d+D}\left(V_{h e n . k}+V_{h c v . k}\right) * \frac{1}{(1+a) h}}{\sum_{h=1}^{d+D}\left(V_{h e n . a}+V_{h c v . a}\right) * \frac{1}{(1+a)^{h}}} \text { (effective income/potential income) }
$$

where, Cok - effective income/potential income - opportunity cost of capital for $\mathrm{k}$ type of renewable energy; $V_{k} \quad$ - monetary units - the annual income during the investment implementing and operating periods, for the chosen type of renewable energy $(\mathrm{k}) ; \mathrm{V}_{\mathrm{a}}-$ monetary units - the annual income during the investment implementing and operating periods, for the given up type of renewable energy (a).

- Local Potential Energy Index - the decision-maker will choose the type of investment which generates the higher level of the indicator.

$$
\boldsymbol{U}_{\boldsymbol{k}}=\frac{\sum_{\boldsymbol{h}=\mathbf{1}}^{12} \boldsymbol{Q}_{\boldsymbol{e}}}{\boldsymbol{S}_{\boldsymbol{m}^{2}}}\left(\mathrm{MWh} / \mathrm{m}^{2} / \text { year }\right)
$$

where, $\mathrm{U}_{\mathrm{k}}-\mathrm{MWh} / \mathrm{m}^{2} /$ year - the local potential energy index for $\mathrm{k}$ type of renewable energy; $\mathrm{Q}_{\mathrm{eh}}-\mathrm{MWh} / \mathrm{month}$ - the monthly amount of energy generated by the investment; $\mathrm{S}_{\mathrm{m}}{ }^{2}-$ $\mathrm{m}^{2}$ - the total area of the production capacity.

- Green Certificates Return Index

- Average Yield for the Reduction of GHG

- Aggregate Installed Power Output

\section{Set of specific indicators:}

- for developing wind power capacities: - Average Wind Speed Per Time Unit; -Wind Efficiency Index; - Wind Amplitude; - Return Rate of Wind Potential;

- for developing sun power capacities: - Shading Coefficient; - Temperature Coefficient for a Module.

\section{Conclusions}

The paper aims to provide a set of global and specific indicators, which are regarded as most suitable for assessing the opportunity and efficiency of investment projects aimed to develop renewable energy production capacities. The article could be continued either by identifying and formalizing the specific indicators for the other types of renewable energy sources (hydropower, the tide power, the geothermal power, the biomass power and the biogas power) or by adding new indicators for assessing the economic efficiency of a renewable energy project 